\author{
UNIVERSIDADE DE SÃO PAULO \\ FACULDADE DE ECONOMIA, ADMINISTRAÇÃO E CONTABILIDADE \\ DEPARTAMENTO DE ECONOMIA \\ PROGRAMA DE PÓS-GRADUAÇÃO EM ECONOMIA
}

\title{
Liquidity shocks and their effects on entrepreneurship
}

Choques de liquidez e os efeitos sobre empreendedorismo

Eugenia Josefina Fernandez Torello

Orientador: Prof. Dr. Gabriel de Abreu Madeira

São Paulo - Brasil

2015 
Prof. Dr. Marco Antonio Zago

Reitor da Universidade de São Paulo

Prof. Dr. Adalberto Américo Fischmann

Diretor da Faculdade de Economia, Administração e Contabilidade

Prof. Dr. Hélio Nogueira da Cruz

Chefe do Departamento de Economia

Prof. Dr. Márcio Issao Nakane

Coordenador do Programa de Pós-Graduação em Economia 


\title{
Liquidity shocks and their effects on
}

\section{entrepreneurship}

Choques de liquidez e os efeitos sobre empreendedorismo

\begin{abstract}
Dissertação apresentada ao Departamento de Economia da Faculdade de Economia, Administração e Contabilidade da Universidade de São Paulo como requisito parcial para a obtenção do título de Mestre em Ciências.
\end{abstract}

Orientador: Prof. Dr. Gabriel de Abreu Madeira

Versão Corrigida

(versão original disponível na Faculdade de Economia, Administração e Contabilidade)

São Paulo - Brasil

2015 
FICHA CATALOGRÁFICA

Elaborada pela Seção de Processamento Técnico do SBD/FEA/USP

Torello, Eugenia Josefina Fernandez

Liquidity shocks and their effects on entrepreneurship / Eugenia Josefina Fernandez Torello. -- São Paulo, 2015.

60- $\mathrm{p}$.

Dissertação (Mestrado) - Universidade de São Paulo, 2015.

Orientador: Gabriel de Abreu Madeira.

1. Empreendedorismo 2. Liquidez 3. Crédito 4. Aposentadoria I. Universidade de São Paulo. Faculdade de Economia, Administração e Contabilidade. II. Título.

CDD - 338.04 
A mi familia 



\section{Agradecimentos}

Gostaria de agradecer a minha família por ter me apoiado nessa etapa. Aos meus pais pelas discussões e contribuições ao meu trabalho. Ao Alan, pelo apoio, paciência e carinho, com certeza esse trabalho não teria sido possível sem ele. Agradeço a turma do IPE/USP pela participação em minha formação e pelos bons momentos. Agradeço também ao Professor Marcos Rangel por sua importante contribuição. Por último, agradeço ao meu orientador Gabriel Madeira que me guiou na elaboração deste trabalho. 



\section{Resumo}

O objetivo do presente trabalho é analisar como choques de liquidez afetam as decisões de empreendedorismo dos domicílios a fim de identificar se os domicílios têm restrições de liquidez. Esse trabalho teve como foco a análise das respostas dos domicílios a choques antecipados de renda, advindas da aposentadoria, desde que com mercados completos, decisões não devem ser afetadas por um choque de liquidez quando o momento e a quantidade do choque são conhecidos. Utilizamos regressão descontínua para estimar este efeito causal, dado que a elegibilidade para aposentadoria por idade é parcialmente determinada pela idade do indivíduo. Os resultados sugerem que proprietários de pequenas empresas brasileiras do setor informal da economia sofrem problemas de liquidez.

Palavras-chaves: empreendedorismo, liquidez, crédito, aposentadoria 



\section{Abstract}

The objective of this study is to analyze how liquidity shocks affect households' decisions related to entrepreneurial activities in order to identify whether households are liquidity constrained. This study focused on households' responses to anticipated income shocks, via the receipt of pension benefits, since under complete markets, decisions should not be affected by a liquidity shock when the timing and amount of that shock are known. We exploited the fact that eligibility rules for old age pension were partially determined by age and used a Fuzzy Regression Discontinuity Design to estimate the causal effects. The results suggest that Brazilian small business owners in the informal sector of the economy are liquidity constrained.

Key-words: entrepreneurship, liquidity, credit, pension benefits 



\section{Sumário}

1 Introduction . . . . . . . . . . . . . . . 19

2 Institutional Background . . . . . . . . . . . . . . 25

2.1 The Pension System in Brazil . . . . . . . . . . . . . . . 25

2.2 Social Security Rules . . . . . . . . . . . . . . . . . 26

3 Data . . . . . . . . . . . . . . . . . 29

3.1 Estimation . . . . . . . . . . . . . . . . . . . . . . . 34

4 Results . . . . . . . . . . . . . . . . . . . . 39

4.1 Validity Tests for the use of a Fuzzy RDD . . . . . . . . . . . . . 39

4.2 Two-Stage Least Squares Results _ . . . . . . . . . . . . . . . . 43

4.3 Discussion of Results . . . . . . . . . . . . . . . . . 46

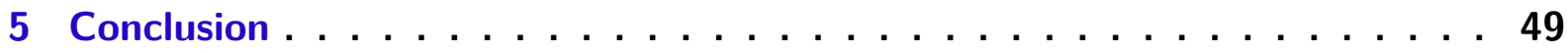

Referências ........................51

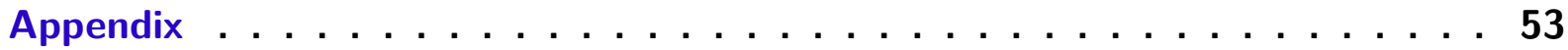





\section{Lista de ilustrações}

Figura 1 - Probability of Treatment: Female Pensioners . . . . . . . . . . . 36

Figura 2 - Manipulation of the Running Variable - McCrary Test . . . . . . . . . 40

Figura 3 - Probability of Treatment: Female Pensioners in Household . . . . . . . 41

Figura A1 - Probability of Treatment: Male Pensioners . . . . . . . . . . . . . 60 



\section{Lista de tabelas}

Tabela 1 - Eligibility Criteria to Obtain Social Security Benefits. . . . . . . . . . 26

Tabela 2 - Summary Statistics of Credit Use and Credit Sources . . . . . . . . . . 31

Tabela 3 - Summary Statistics of Pensioners . . . . . . . . . . . . . 32

Tabela 4 - Summary Statistics of Entrepreneurs. . . . . . . . . . . . . . 33

Tabela 5 - Entrepreneurial Decisions and Pensioners in Household. . . . . . . . . 34

Tabela 6 - Predetermined Characteristics . . . . . . . . . . . . . . . . . 41

Tabela 7 - Probability of Treatment and Liquidity Shock in Household . . . . . . 42

Tabela 8 - Effcts of a Liquidity Shock on Entrepreneurial Decisions . . . . . . . 44

Tabela A1 - Description of Outcome Variables . . . . . . . . . . . . . . . 53

Tabela A2 - First-Stage Results . . . . . . . . . . . . . . . . . . 54

Tabela A3 - Further Functional Forms . . . . . . . . . . . . . . . . 55

Tabela A4 - 2SLS Results Not Including Observations at the Cutoff . . . . . . . . . 57

Tabela A5 - 2SLS Results Using Smaller Age Intervals . . . . . . . . . . . . . . . 58 



\section{Introduction}

Borrowing constraints is an issue of great concern for development economists. It is well argued in the literature that credit constraints affect the development process of a country. ${ }^{1}$ Unequal access to credit may leave poor individuals unable to invest the optimal amount in their business. It could also affect the transition of individuals from wage-earners to entrepreneurs. ${ }^{2}$ This in turn could lead to an inefficient allocation of resources in the economy, with suboptimal degrees of investment and talent that affect the long term growth of a country. This has also pervasive effects on inequality, reducing the opportunities of the most vulnerable to overcome poverty. This is an issue particularly relevant in developing countries where credit constraints are more severe. ${ }^{3}$ Thus, researching how entrepreneurs are constrained is crucial for economic development. With this in mind, the present study investigates the effects of anticipated income shocks on households' decisions about entrepreneurship to identify if households suffer liquidity constraints. This is studied using data from a survey of small entrepreneurs in the informal sector of the economy in Brazil.

The literature concerned with identifying constraints empirically have taken different approaches. As explained by Banerjee and Duflo (2005), some authors have studied the impact of credit constraints by using close substitutes for credit, such as parental wealth, family assets, and community wealth. For instance, Evans and Jovanovic (1989) found a positive and significant relation between the probability of entering self-employment and initial family assets. Dunn and Holtz-Eakin (2000) found that financial assets of young men had a significant effect on the probability on self-employment and on the transition of becoming a self-employed. For the case of Brazil, Assunção and Alves (2007) found a significant relation between wealth and intra-household decisions (decision of the head of household and the spouse to engage in entrepreneurial activities). However, the use of these substitutes for credit might underestimate the effects of other unobserved household

$1 \quad$ See Galor and Zeira(1993), Banerjee and Newman (1993), Aghion and Bolton (1997), Ghatak and Jiang (2002).

2 See Cagetti and Dinardi (2006).

3 Banerjee and Duflo (2005). 
and individual characteristics, such as ability, which could also affect individuals' decisions about engaging in entrepreneurial activities.

With this issue in mind, other authors have focused their study on exogenous measures of wealth variation by using windfall gains, such as lottery winnings or inheritances, to see how these shocks affected investment decisions. For instance, Lindh and Ohlsson (1996) used lottery winnings and inheritances and found an increase in the probability of entry into self-employment for individuals who had received these income shocks. Holtz-Eakin et al. (1994) also used inheritances as an income shock and found that, conditioned on becoming an entrepreneur, inheritances had a significant impact on capital investment.

Using unanticipated shocks in income to measure how individuals' investment decisions are affected provides interesting evidence, but there are certain caveats about this method. Firstly, it is difficult for the researcher to observe whether changes in income are in fact unanticipated for the individual, except maybe in the case of lottery winnings. Secondly, even if the researcher is able to observe unexpected shocks, changes in individuals' investment decisions are not necessarily evidence of credit constraints.

Recent research has focused on investigating individuals' responses to anticipated shocks in income. The consumption smoothing life cycle/permanent income hypothesis models state that rational, forward-looking individuals plan their optimal consumption based on their present income and the present value of their expected future income. An unanticipated permanent income shock, that changes expectations about future income, will affect consumption. On the other hand, anticipated variations in income, where the timing and the amount of the income are known, should not affect households' decisions. With complete markets, individuals can borrow in anticipation of an income increase and smooth consumption. However, when individuals do not have access to credit, decisions will become sensitive to the time the income increase materializes (JAPELLI; PISTAFERRI, 2010).

In the present study we pension benefits as an anticipated income shock in the household. In Brazil, pension benefits are considered an important tool to combat elderly 
poverty, they are the principal component of non-labor earnings in the household and represent a significant portion of total household income. Moreover, since the data we used is restricted to the informal sector of the economy, an income shock in households in this sector may affect decisions about consumption as well as decisions about investment in the production unit allowing us the study of effects of a shock on entrepreneurship decisions. ${ }^{4}$ Therefore, in order to analyze if households are liquidity constrained we compare entrepreneurial decisions in households with a pensioner vis-à-vis households with an individual near the pension eligibility threshold.

The empirical strategy used in this study is based on the work by Edmonds (2006) who studied the effects of anticipated income shocks on households' decisions about allocation of children's time in the South African black population. He used pensions as a variation of income to measure how these shocks affected households' decisions about schooling and child labor. In order to infer a causal relationship, he took advantage of the discontinuity in pension eligibility rules for old age pension and used the method of regression discontinuity design (RDD). As in Edmonds (2006), we exploit the discontinuity in pension eligibility rules for old age pension in Brazil and use RDD. In our case, a Fuzzy RDD is used. Given that female pensioners in Brazil are more likely to retire for old age and their pension benefits have a more significant positive impact on household income, only households with female pensioners are considered.

This study adds to the literature of the effects of liquidity constraints on household decisions by analyzing data about small entrepreneurs in Brazil. Moreover, the survey used in this study has information related to micro-entrepreneurship, allowing the analysis of the effects of liquidity shocks on a different set of outcomes than what is usually studied in the literature. We looked at the effect of liquidity constraints on seven different measures of entrepreneurial decisions. These included: investment decisions, business performance, probability of using informal credit, probability of leaving the business, and the probability

4 Households that operate small enterprises in the informal sector are characterized by the lack of separation between capital and labor as production inputs. Here, the separation property fails and households make simultaneous decisions about production and consumption (BARDHAN; UDRY, 1999). 
of the entrepreneur being an employer instead of a self-employed individual. Both the probability of expanding the business and the probability of leaving the business are self-reported measures. Leaving the business should be interpreted as a probability of leaving the business, because of struggles or difficulties, to look for other opportunities outside of entrepreneurship.

Results showed that having a female pensioner in the household, and thus receiving a liquidity shock, decreased the probability of the entrepreneur leaving the business to look for a salaried job. Moreover, receiving a liquidity shock positively affected the probability of an individual being an employer instead of a self-employed individual. No significant results were found related to investments in the business, business performance, or use of informal credit.

The lack of effects on investment decisions and business performance should not be hastily interpreted to mean that these individuals are no constrained. Traditional models of liquidity constraints, as Evans and Jovanovic (1989), associate constraints to capital investments. Here, the population studied is restricted to small business owners, operating mostly labor-intensive businesses. Therefore, the fact that a liquidity shock did not have an impact on capital-related decisions is more likely because of the nature of these types of businesses and not because these individuals are not liquidity constrained. Indeed, the positive effect found on the probability of being an employer is an indication that constraints are an issue, affecting in this case the scale of the business in relation to the hiring of labor.

The significant results found on the probability of leaving the business are further evidence that these individuals are credit constrained. This result suggests that having a liquidity shock in the household diminishes the need for the entrepreneur to look for a salaried job and enables him to stay with the business. Since this variable is selfreported by individuals, a liquidity shock possibly acts as a buffer against negative shocks. Entrepreneurs receiving a liquidity shock may feel protected against risks, with an insured income, and therefore able to continue with the entrepreneurial activity. 
This paper is organized as follows. The next section discusses a brief history of the social security system in Brazil and describes the current retirement rules relevant to this study. Section 3 describes the data used and explains the empirical strategy. Section 4 provides validity tests for the use of RDD and presents the results of the study. Section 5 concludes. 



\section{Institutional Background}

\subsection{The Pension System in Brazil}

Social security was introduced in Brazil in 1923 under the Elói Chaves law. In its early stages, it was a private system managed by employers and employees and participation was voluntary. It was initially restricted to railroad workers, but later extended to other types of workers. In 1930, the government created the Institute for Retirement and Pensions (Instituto de Aposentadoria e Pensões) to unify all privately-managed funds. Then, in 1960 the government passed a law (Lei Orgânica da Previdência Social) specifying a common legal framework for all funds. By the 1970s, social security benefits were extended to almost all workers including domestic and rural workers.

In 1988, a new constitution was passed declaring social security to be a basic right for all citizens. To this purpose, the law established a minimum benefit for all pensions equal to the minimum wage. Also, the government created a non-contributing social pension scheme to benefit the elderly and persons with disabilities from low income families. In addition, the eligibility age for rural workers' benefits was reduced by five years. Lastly, in 1990, the government created the National Institute for Social Security (Instituto Nacional do Seguro Social), as a product of merging the Institute for Retirement and Pensions with the Institute of Financial Administration of the Social Security (Instituto de Administração Financeira da Previdência e Assistência Social).

During the presidency of Fernando Henrique Cardoso (1995-2002) social security underwent another wave of reforms, this time regarding the formula used to calculate benefits. There were concerns about the financial sustainability of the system, and therefore in 1998 Congress approved a constitutional amendment allowing the benefit formula to be defined by an ordinary law. Later, in 1999, Congress passed a law introducing the social security factor ( fator previdênciario), ${ }^{1}$ an adjustable formula based on actuarial

1 The social security factor is an actuarial coefficient to define pensioners' benefits that takes into account time of contribution of the pensioner, age, and life expectancy. The formula is given by: $f=(T c * a) / E s *[1+(I d+T c * a) / 100]$ where $T c$ is time of contribution, $a$ is the rate of contribution, $E s$ is life expectancy at time of retirement, and $I d$ is the age of the pensioner. 
rules designed to discourage early retirement.

\subsection{Social Security Rules}

In the current social security system an individual may retire from disability, old age, and time of contribution. Eligibility rules and benefits vary by retirement category, according to gender, and whether the individual is from a rural or urban area. Table 1 summarizes this information. Female private sector workers from urban areas may retire after completing 30 years of contribution, or for old age after reaching 60 years of age. Males can retire after completing 35 years of contribution, or for old age after turning 65 .

Table 1 - Eligibility Criteria to Obtain Social Security Benefits.

\begin{tabular}{|c|c|c|}
\hline & Female & Male \\
\hline \multicolumn{3}{|c|}{ Contributing System } \\
\hline \multirow{4}{*}{$\begin{array}{l}\text { Urban Private } \\
\text { Sector }\end{array}$} & Old Age: 60 years old & Old Age: 65 years old \\
\hline & $\begin{array}{l}\text { and } 180 \text { months of } \\
\text { contribution. }\end{array}$ & $\begin{array}{l}\text { and } 180 \text { months of } \\
\text { contribution. }\end{array}$ \\
\hline & Length of Contribution: & Length of contribution: \\
\hline & $\begin{array}{l}30 \text { years of } \\
\text { contribution. }\end{array}$ & $\begin{array}{l}35 \text { years of } \\
\text { contribution. }\end{array}$ \\
\hline \multirow{2}{*}{$\begin{array}{l}\text { Rural Private } \\
\text { Sector }\end{array}$} & 55 years old and 180 & 60 years old and 180 \\
\hline & $\begin{array}{l}\text { months of rural } \\
\text { activity }\end{array}$ & $\begin{array}{l}\text { months of rural } \\
\text { activity }\end{array}$ \\
\hline Public Sector & $\begin{array}{l}55 \text { years old and } 30 \\
\text { years of contribution. }\end{array}$ & $\begin{array}{l}60 \text { years old and } 35 \\
\text { years of contribution. }\end{array}$ \\
\hline \multicolumn{3}{|c|}{ Non-Contributing System } \\
\hline \multirow{4}{*}{$\begin{array}{l}\text { Old age and } \\
\text { persons with } \\
\text { disabilities }\end{array}$} & 65 years old and & 65 years old and \\
\hline & household per capita & household per capita \\
\hline & income lower than one & income lower than one \\
\hline & $\begin{array}{l}\text { quarter of the } \\
\text { minimum wage }\end{array}$ & $\begin{array}{l}\text { quarter of the } \\
\text { minimum wage }\end{array}$ \\
\hline
\end{tabular}

Note: After the 1998 reforms, the minimum contribution was 10 years for old age urban private sector workers. It increased gradually to 15 years after 2005 Before the reforms of 1998, public sector workers had no minimum age requirement.

Workers from rural areas are subjected to more lenient rules: women can retire after turning 55 and men after turning 60 . Rural workers do not need to explicitly contribute to the system in order to receive benefits, but they need to prove they have worked in 
rural activities for at least 180 months. Rules vary also for public sector workers. Lastly, there is a non-contributing social retirement scheme. To be eligible to receive this benefit individuals must be older than 65 or have a disability, and have a household income lower than one quarter of the minimum wage. ${ }^{2}$ The benefit received is equal to the value of one minimum wage.

Until the reforms of 1998, the social security system was more flexible. Pensioners were able to retire after contributing for 10 years, after reaching the age for old age retirement, or after proving to have worked for a number of years without necessarily having contributed to the system (BONTURI, 2002). Also, before 1999 the social security factor did not affect the social security benefits.

The social security system in Brazil has several characteristics that make it useful in the study of the effect of liquidity shocks on household decisions. Social security benefits are considered an important tool to combat elderly poverty. Benefits have a minimum value equal to one minimum wage and there are non-contributing schemes for the rural population and the elderly in low-income households. Barros et al (2008) explain that social security benefits are one of the principal components of non-labor earnings in the household. Also, it is legal to continue working after retirement, allowing the possibility of earning both social security benefits and labor income. Moreover, the data used in this study shows that households are multi-generational and that elders live in households with an average size of four individuals. This makes it possible to share pension benefits with other individuals in the household.

Taking advantage of the characteristics of the Brazilian social security system, other studies have used pension benefits to analyze its impact on household decisions, such as child labor and female living arrangements. ${ }^{3}$

$\overline{2}$ Originally, the minimum age required to obtain this benefit was 70 years old, but it was reduced to 67 in 1998 and then to 65 in 2003. The eligibility requirements to receive this benefit are revised every two years to see if individuals still meet the criteria.

3 See Carvalho (2008), Carvalho (2012), Reis and Camargo (2007). 



\section{Data}

To analyze if a liquidity shock affects households' decisions, this study uses data from a survey conducted by the Brazilian statistical office (Instituto Brasileiro de Geografia e Estatística, IBGE), called The Informal Urban Economy (Economia Informal Urbana, ECINF), with waves in 1997 and 2003. The survey was conducted with the intention of shedding some light on the Brazilian informal sector, exploring the dimensions of this sector, as well as its importance to the economy. It covers all non-agricultural economic units engaged in the production of goods and services for the purpose of creating jobs and generating income to the individuals concerned; it excludes those units where production of goods is exclusively for own final use. The focus of the survey is on owners of informal businesses, that is, self-employed workers and employers with up to five employees, from all Brazilian state capitals and metropolitan areas. ${ }^{1}$

The survey was carried out using a stratified sampling procedure. The primary sampling units (PSUs) within each geographical area were selected using systematic sampling with probabilities proportional to the number of households. ${ }^{2}$ Next, households were listed to determine if they had a self-employed individual or an employer with up to five employees, and the type of economic activity of the production unit. With this list of households belonging to the informal sector by economic activity, a stratified sample was selected. ${ }^{3}$

The survey contains data on the production unit and on demographic characteristics of the owner and other household members. There is information about age, gender, and race of all household members; work-related information of all individuals older than 10 years old; characteristics of self-employed individuals and employers with up to five employees; characteristics of the production unit; value of revenues, costs, investments, assets and equipment, credit, and debts; and characteristics of the employees. Unlike data

$1 \quad$ Non-agricultural activities performed by individuals living in rural areas were excluded from the survey because of a significant increase in operational costs.

2 The number of households present at the time of the previous population census.

3 Whenever households had more than one informal sector entrepreneur, the least frequent activity (in general, all activities that were not in the commerce and services categories) was included. 
used in other studies of credit constraints, this survey has information about characteristics of small business owners and allows the study of different effects related to liquidity constraints.

The present work will use only the 1997 wave of the survey because it has more information regarding demographic characteristics of the household. ${ }^{4}$ To our knowledge, ECINF has never been used to study the causal effects of a liquidity shock on entrepreneurship unlike other Brazilian national surveys like PNAD. Moreover, from 2003 onward, the credit market in Brazil underwent a series of reforms that dramatically increased access to credit. Therefore, assessing the impacts of liquidity constraints on household decisions before these reforms may provide further insights into the ex-ante constraints of this population.

The fact that the survey is restricted to the informal sector of the economy allows the study of a population where the lack of credit access is usually a problem. In Table 2 there is information about credit use and resources used for investments and initial capital for all self-employed individuals and employers in the sample. Only $5 \%$ of entrepreneurs reported having used credit in the three months preceding the survey, and among those who had used credit, less than half reported having obtained credit through private or public banks. Regarding resources used for initial capital and for investments, only $1 \%$ used bank loans for starting their business, and only 5\% used credit from banks for their investments. These figures clearly indicate that the vast majority of individuals in this sector of the population do not use credit.

Given that the survey contains information on credit use and this also includes loans from friends and family, this study will also look at the effects of a liquidity shock on the use of informal credit sources. With complete markets, individuals in need of financing and able to repay loans should not have to resort to informal sources of credit. Therefore, if households are liquidity constrained, when receiving a liquidity shock, the expected effect would be that the use of informal credit sources decreases.

$\overline{4}$ The 2003 wave only has information about the work status of the members of the household. In addition, the self-reported value of pension benefits for the 2003 wave presented unusual results. 
Table 2 - Summary Statistics of Credit Use and Credit Sources

\begin{tabular}{lc}
\hline \hline & Full Sample \\
\hline Credit use & \\
Used credit in the past 3 months (\%) & 4.83 \\
Source of credit (\%)* & \\
Friends/relatives & 33.7 \\
Private/Public banks & 41.71 \\
Supplier & 10.2 \\
Other business/people & 10.34 \\
Other & 3.77 \\
No answer & 0.29 \\
Paying debt (\%) & 16.45 \\
Resources for initial capital (\%) & \\
Compensation & 10.1 \\
Inheritance & 2.25 \\
Savings or sale of goods & 10.74 \\
Other personal resources & 33.07 \\
Loans from relatives/friends & 7.36 \\
Bank Loans & 1.22 \\
Other companies & 1.3 \\
Business Partner & 1.51 \\
No capital needed & 29.36 \\
Other & 2.99 \\
No answer & 0.1 \\
Resources for investments (\%) & \\
Past profits & 63.33 \\
Bank Loans & 5.23 \\
Other types of loans & 7.61 \\
Nother & 23.6 \\
\hline \hline & 0.22 \\
\hline For answer & \\
\hline
\end{tabular}

*For those who used credit

Since information about type of retirement is not precisely recorded in the survey, ${ }^{5}$ pension eligibility will be determined by whether an individual reaches pension eligibility age. In order to asses if this assumption is supported by the data, it is important to see the number of pensioners who are above the age eligibility requirement for old age pension. Table 3 presents demographic characteristics of the pensioners in the sample. $65 \%$ of female pensioners are above the eligible age for old-age retirement. The percentage of males above the eligibility age is smaller: $44 \%$ of men are above 65 years old. This is in line with

5 The survey only contains information regarding whether individuals receive social security benefits and the amount of this benefit. 
evidence in Brazil that shows that the majority of women retire for old age, whereas the majority of men retire for years of contribution. Considering the characteristics of the data and the differences in retirement decisions between females and males, the focus of this study will be only on female pensioners. Therefore, pension eligibility will be determined by whether females are 60 years or older.

Table 3 - Summary Statistics of Pensioners

\begin{tabular}{|c|c|c|c|}
\hline & Full Sample & Male & Female \\
\hline $\mathrm{N}$ & 10,605 & 5,719 & 4,886 \\
\hline Percent Working & 34.71 & 45.32 & 22.29 \\
\hline \multicolumn{4}{|l|}{ Age distribution (\%) } \\
\hline Younger than 40 & 4.02 & 3.97 & 4.07 \\
\hline $40-49$ & 9.44 & 9.21 & 9.7 \\
\hline $50-54$ & 10.69 & 11.75 & 9.46 \\
\hline $55-59$ & 13.48 & 14.71 & 12.05 \\
\hline $60-64$ & 17.03 & 16.51 & 17.64 \\
\hline $65-69$ & 16.57 & 16.68 & 16.43 \\
\hline $70-74$ & 13.2 & 13.53 & 12.81 \\
\hline Older than 74 & 15.57 & 13.64 & 17.83 \\
\hline \multicolumn{4}{|l|}{ Pension Income Group (\%) } \\
\hline$>0 \&<$ minimum wage $(\mathrm{mw})$ & 1.9 & 1.69 & 2.16 \\
\hline$=\mathrm{mw}$ & 51.77 & 41.7 & 63.54 \\
\hline$>\mathrm{mw} \&<=2 \mathrm{mw}$ & 13.14 & 14.55 & 11.48 \\
\hline$>2 \mathrm{mw} \&<=4 \mathrm{mw}$ & 11.19 & 13.6 & 8.36 \\
\hline$>4 \mathrm{mw} \&<=8 \mathrm{mw}$ & 12.61 & 16.71 & 7.81 \\
\hline$>8 \mathrm{mw}$ & 9.4 & 11.74 & 6.66 \\
\hline \multirow[t]{2}{*}{ Mean pension Income $(\mathrm{R} \$)$} & 406 & 493 & 303 \\
\hline & $(713)$ & $(835)$ & $(519)$ \\
\hline Median Pension Income $(\mathrm{R} \$)$ & 120 & 180 & 120 \\
\hline
\end{tabular}

Note: Standard errors in parentheses. Income is in 1997 Brazilian Reais levels.

Minimum wage in Brazil for the year 1997 was $\mathrm{R} \$ 120$.

Moreover, the data in Table 3 indicate that around $64 \%$ of women receive pension benefits equal to one minimum wage, compared to $42 \%$ of men. Pensioners who receive a pension benefit equal to one minimum wage are more likely to have earned labor income either less than, or equal to, this benefit. This could imply that receiving pension benefits results in a more significant impact on household income for households with female pensioners, and thus might potentially result in a larger effect on household decisions.

Since the focus of this study is on the impact of liquidity constraints on entrepre- 
neurship, Table 4 presents descriptive statistics of the entrepreneurs in the sample by gender. We can see that the mean age of entrepreneurs is around 40 years old, and that most entrepreneurs have low levels of education; the majority of them reports having only some primary school completed. Looking at the business activity group categories, the most prevalent activity is wholesale and retail, followed by community and social services, indicating that most entrepreneurs engage in labor-intensive activities. Lastly, around $19 \%$ of entrepreneurs live in a household with a female pensioner and less than $7 \%$ are pensioners themselves.

Table 4 - Summary Statistics of Entrepreneurs.

\begin{tabular}{lccc}
\hline \hline & Full Sample & Male & Female \\
\hline N & 43,433 & 28,410 & 15,023 \\
Age (mean) & 40.04 & 40.36 & 39.43 \\
Education (\%) & & & \\
No/less than one year & 9.55 & 10.7 & 7.38 \\
Some Primary School & 44.91 & 47.39 & 40.21 \\
Primary School Complete & 12.01 & 11.78 & 12.43 \\
Some High School & 7.2 & 6.68 & 8.19 \\
High School Complete & 16.94 & 14.78 & 21.02 \\
University/College Complete & 2.45 & 2.44 & 2.48 \\
Some University/College & 6.83 & 6.12 & 8.16 \\
No answer & 0.11 & 0.1 & 0.13 \\
Business Activity Group (\%) & & & \\
Manufacturing and Mining & 12.92 & 10.32 & 17.83 \\
Construction & 12.73 & 19.34 & 0.21 \\
Wholesale \& Retail & 26.55 & 22.89 & 33.46 \\
Accommodation \& Food Services & 9.28 & 7.71 & 12.26 \\
Transportation & 8.51 & 12.71 & 0.55 \\
Other Community and Social Servs & 18.33 & 15.61 & 23.48 \\
Technical Services & 11.28 & 10.96 & 11.88 \\
Other Services & 0.4 & 0.45 & 0.31 \\
No answer & 0.01 & 0.01 & 0.01 \\
Household with pensioner (\%) & 18.72 & 17.8 & 20.47 \\
Pensioner (\%) & 6.56 & 7.24 & 5.28 \\
\hline \hline
\end{tabular}

The test of households investment decisions and business performance responses to anticipated income changes relies on comparing households with no pensioners to households with pensioners, the former having thus received a liquidity shock. Table 
5 compares summary statistics of the outcome variables between these two groups. ${ }^{6}$ Comparing the last two columns, having a pensioner in the household presents inconclusive effects. The percentage of entrepreneurs who have invested in their business is larger for households with a pensioner and the percentage of difficulties encountered by their business is smaller in households with a pensioner. On the other hand, average value of investments is smaller in households with a female pensioner and the percentage of entrepreneurs who look to expand their business is also smaller for that group. However, these simple comparisons are not evidence of any relationship of causality, since households with pensioners may systematically differ from households with no pensioners. The next section explains the methodology used to address this issue.

Table 5 - Entrepreneurial Decisions and Pensioners in Household.

\begin{tabular}{lcccc}
\hline \hline & $\begin{array}{c}\text { Full } \\
\text { Sample }\end{array}$ & $\begin{array}{c}\text { HH with } \\
\text { no } \\
\text { pensioners }\end{array}$ & $\begin{array}{c}\text { HH with } \\
\text { female } \\
\text { elders and } \\
\text { no pensioners }\end{array}$ & $\begin{array}{c}\text { HH with } \\
\text { female } \\
\text { pensioners }\end{array}$ \\
\hline Business Performance & & & & \\
Invested in the past year (\%) & 23.6 & 25.7 & 18.99 & 20.27 \\
Encountered difficulties (\%) & 34.78 & 33.57 & 37.7 & 36.11 \\
Plans to expand business (\%) & 42.25 & 45.54 & 36.23 & 34.49 \\
Plans to leave business (\%) & 10.93 & 11.86 & 8.95 & 9.3 \\
Employer (\%) & 15.61 & 16.68 & 13.24 & 13.92 \\
Used credit from an informal source (\%) & 76.64 & 76.73 & 78.1 & 72.88 \\
Mean investments (R\$) & 936 & 1037 & 752 & 712 \\
& $(5883)$ & $(6397)$ & $(4887)$ & $(4212)$ \\
Mean investments (R\$, logarithm) & 1.54 & 1.7 & 1.21 & 1.31 \\
\hline \hline
\end{tabular}

Note: Standard errors in parentheses.

\subsection{Estimation}

The objective of this study is to investigate if there is a causal effect of a liquidity shock on household decisions, and therefore identify whether households are liquidity constrained. The study uses pension benefits as a liquidity shock to evaluate how an anticipated shock in permanent income affects entrepreneurial decisions. However, there are certain issues that make the identification of a causal relationship difficult. For instance,

\footnotetext{
$\overline{6}$ A description of the outcome variables can be found on Table A1 in the Appendix.
} 
there could be unobserved effects or characteristics that could also affect household decisions and bias our estimates.

Since old age pension eligibility status is determined by age, we can exploit this exogenous source of variation to compare households with elders near (but below) pension eligibility age, to households with elders of pension age. This allows the comparison of households with similar characteristics in terms of age and related variables affected by age, but who differ in the receipt of pension.

For this end, the method of regression discontinuity design (RDD) is used, where the treatment status is obtained by determining whether a given observed variable, also known as a forcing variable, lies above a known threshold. In this case, the treatment indicator is whether a household has a female pensioner, and this is determined by the age of the oldest female in the household (as in Edmonds (2006)) where the threshold used is age $60 .^{7}$

To identify the causal effect of interest, we compare entrepreneurial decisions of individuals living in a household with an individual (female) near the eligibility age for retirement, with individuals living in a household with an individual (female) who has already reached pensioner age. This is based on the premise that households with nearly eligible females share similar characteristics with households with eligible females. The only difference is that the latter household receives social security benefits.

As explained in Imbens and Lemieux (2008), in a sharp RDD the assignment of individuals into treatment and control groups is a deterministic function of the forcing variable. Individuals with a forcing variable with a value above a threshold are assigned to treatment while individuals with a forcing variable value less than the known threshold are assigned into a control group.

The use of pension benefits may indicate that in this case treatment status is partially determined by the eligibility rule. It is possible to have individuals reaching retirement age but not being able to retire, or individuals retiring earlier. Figure 1 graphs

760 is the age to become eligible for old age pension benefits for women. 
Figure 1 - Probability of Treatment: Female Pensioners

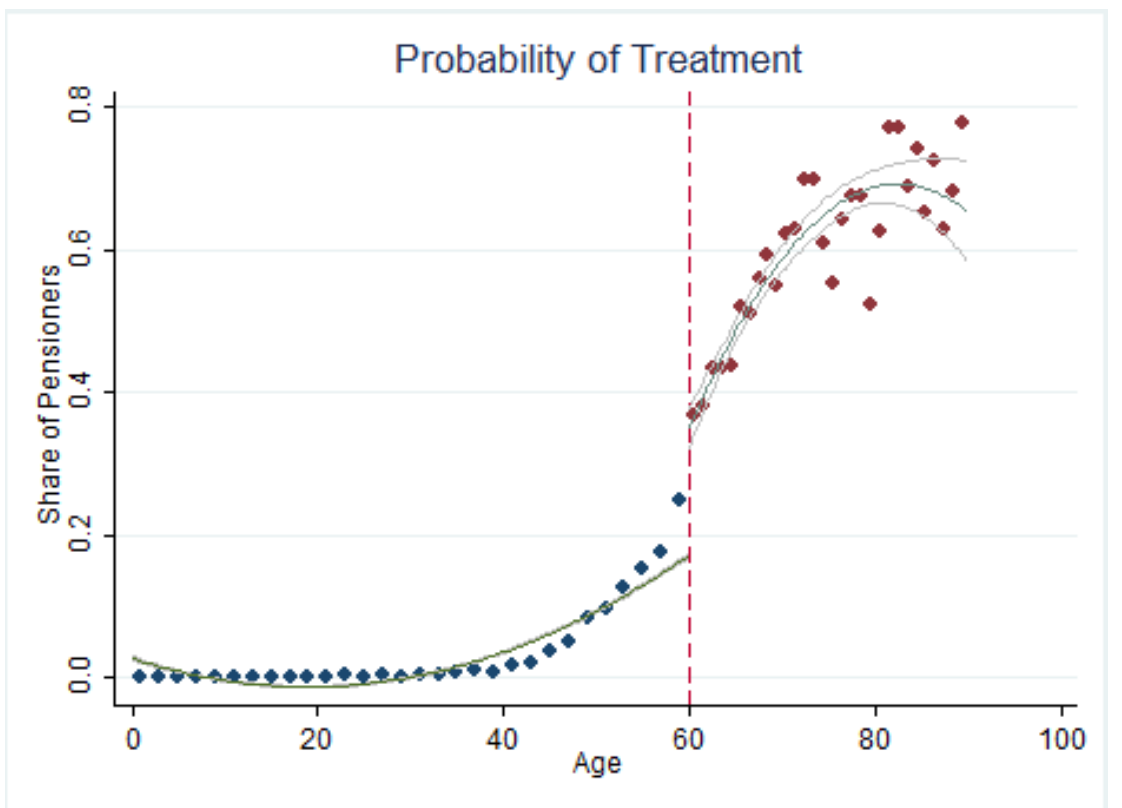

Graph of the conditional mean of female pensioners given age. 30 bins were used on either side of the cutoff as well as a quadratic line of best fit with a $95 \%$ confidence interval.

the conditional probability of a female being a pensioner given her age. As we can see, there is a discontinuity at age 60, the age requirement for receiving old age pension benefits, but the probability does not jump from 0 to 1 crossing the threshold. ${ }^{8}$ Since the age eligibility rule does not perfectly determine retirement, and since the reasons for retiring are not observed, and these reasons might be correlated to the impacts being measured, estimates could be inconsistent.

In order to address this issue, the literature suggests the use of an Instrumental Variable estimation strategy where the exogenous assignment to treatment, the age eligibility rule, is an instrument for the actual treatment, retiring. This is called a Fuzzy RDD. Here, treatment status is partially determined as a discontinuous function of age (LEE; LEMIEUX, 2010; ANGRIST; PISCHKE, 2008). In the case of a Fuzzy RDD, a local average treatment effect (LATE) is estimated, comparing individuals assigned to treatment and actually being treated, to individuals assigned to the control group and

$\overline{8}$ The conditional probability of a male being a pensioner given age was also graphed in Figure A1 in the Appendix and there was no discontinuity. 
actually not being treated (JACOB et al., 2012). In order to estimate these effects, the literature frequently uses a parametric approach. Hahn, Todd and Klaauw (2001) suggest the use of two-stage least squares for this estimation.

$$
\begin{array}{ll}
{[1]:} & I_{i}=\alpha_{2}+\beta_{0} P_{i}+f_{1}\left(a_{i}\right)+\pi_{1} X+\mu_{i} \\
{[2]:} & P_{i}=\alpha_{1}+\gamma_{0} D_{i}+f_{2}\left(a_{i}\right)+\epsilon_{i}
\end{array}
$$

where:

$D_{i}=\left\{\begin{array}{l}0 \text { if oldest female in } h h<60 \\ 1 \text { if oldest female in } h h>=60\end{array}\right.$

and:

$P_{i}=\left\{\begin{array}{l}0 \text { if no female pensioner in } h h \\ 1 \text { if female pensioner in } h h\end{array}\right.$

$I$ in equation [1] represents the outcome effects of interest (measures related to investment decisions, business performance, informal credit use, etc.), and $X$ is a vector of covariates that could have an impact on the outcome variables (household controls, region controls, and entrepreneur individual characteristics). ${ }^{9}$ The functional forms $f_{1}\left(a_{i}\right)$ and $f_{2}\left(a_{i}\right)$ denote the relationship between age of the oldest female in the household and: the receipt of treatment for individual $i$, and the outcome variables of interest, respectively. ${ }^{10}$ Equation [2] represents the first stage of the relationship between the assignment to treatment and the effective treatment.

Here, the coefficient of interest is $\beta_{0}$ and it measures the change in $I$ that comes as a result of having a female moving from nearly eligible to receive social security benefits to actually receiving benefits.

9 See Table A1 in the Appendix for a detailed explanation of the outcome variables.

10 Linear, quadratic, and cubic functional forms, with their interactions are used in the literature; see Jacob et al. (2012) 



\section{Results}

The objective of this study is to evaluate the causal impact of a liquidity shock on households' entrepreneurial decisions. This section presents the main results of the estimation strategy discussed in the previous chapter. First, validity tests for the use of Fuzzy RDD are presented. Secondly, results obtained from the two-stage least squares estimates are presented.

\subsection{Validity Tests for the use of a Fuzzy RDD}

Regression Discontinuity Design is a powerful tool that enables the estimation of treatment effects in a non-experimental setting. For the estimation to be valid, there are two important assumptions that should be checked. First, assignment of individuals into treatment and control groups should be randomly determined by the cutoff rule; that is, individuals should not be able to manipulate the assignment rule in order to receive treatment. Secondly, individuals below the cutoff should not systematically differ from individuals above the cutoff (except for the result of the treatment itself). This allows the comparison of similar groups where only treatment varies by group. In addition, in the case of a Fuzzy RDD, it is important to show that the assignment rule is associated with actual treatment status.

The assumption of no manipulation of the running variable does not present a problem in this study since the assignment rule is determined by age, which is not possible to manipulate. However, since the dataset is restricted to small business owners of the informal sector of the economy, there could be a selection bias where pensioners are not randomly distributed in this population. Therefore, to validate this assumption, a formal

test proposed by McCrary (2008) was carried out. The test measures if there is a change in the density of the distribution of the assignment variable at the cutoff. The test failed to reject the assumption of continuity at the cutoff. Figure 2 presents the results of this test. The figure does not show a discontinuity around the cutoff of age 60 thus validating 
Figure 2 - Manipulation of the Running Variable - McCrary Test

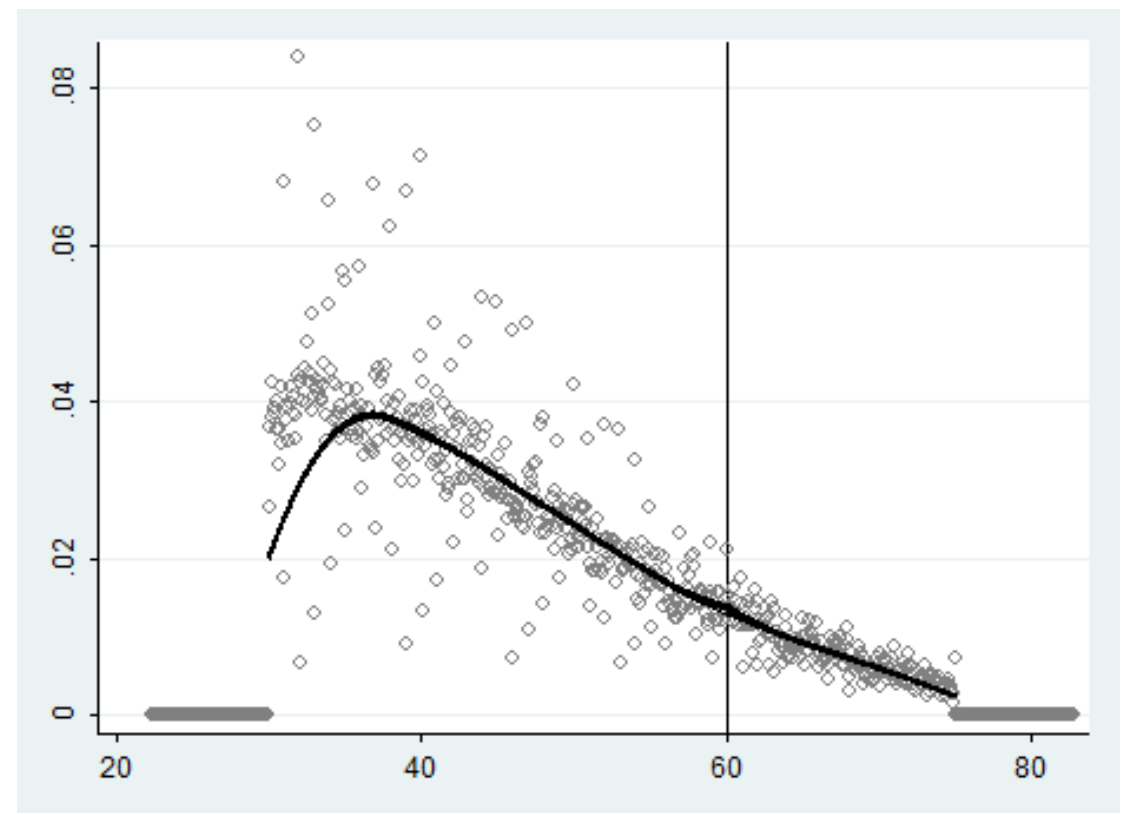

the non-manipulation assumption. ${ }^{1}$

Another important assumption for the validity of RDD is that predetermined characteristics should be balanced for individuals below and above the cutoff. In order to test this assumption, statistics of individual characteristics of entrepreneurs and household characteristics are presented in Table 6 for households where the oldest female is less than 60 years of age, and for households where the oldest female is older than 60. Characteristics for entrepreneurs include: average age, percentage of females, percentage of individuals with up to some primary education, and percentage of entrepreneurs whose business is capital intensive. Household characteristics include: average number of individuals in household, whether household is owned, and the average number of rooms in the household. When considering the full sample, groups appear to be different in several characteristics, but these differences become smaller and insignificant when considering smaller intervals of age around the cutoff. However, because some variables still present differences that are significant, to avoid a possible bias in the estimates, regressions controlling for these variables are also performed.

$1 \quad$ The test and Figure 2 was implemented in Stata using the DCdensity command, obtained from McCrary (2008). 
Table 6 - Predetermined Characteristics

\begin{tabular}{l|ccc|cccc|ccc}
\hline \hline \multirow{2}{*}{ Variables } & \multicolumn{4}{|c|}{ Full Sample } & \multicolumn{3}{c}{ Only HHs with female 50-75 } & \multicolumn{3}{c}{ Only HHs with female 55-65 } \\
& Below & Above & Diff & Below & Above & Diff & Below & Above & Diff \\
\hline Entrepreneur Characteristics: & & & & & & & & & \\
Age & 38.99 & 47.06 & $-8.069^{* * *}$ & 46.70 & 47.46 & $-0.760^{* * *}$ & 47.34 & 47.75 & -0.410 \\
Female & 0.352 & 0.407 & $-0.055^{* * *}$ & 0.398 & 0.409 & -0.011 & 0.391 & 0.397 & -0.006 \\
Primary Education & 0.542 & 0.548 & -0.006 & 0.589 & 0.546 & $0.043^{* * *}$ & 0.607 & 0.555 & $0.051^{* *}$ \\
Capital Intensive Ind. & 0.256 & 0.252 & 0.004 & 0.246 & 0.251 & -0.004 & 0.249 & 0.240 & -0.009 \\
Obs. & 36,705 & 5,167 & & 6,216 & 4,564 & & 2,595 & 2,164 & \\
Household Characteristics: & & & & & & & & & \\
Household size & 4.363 & 4.396 & -0.033 & 4.512 & 4.365 & $0.147^{* * *}$ & 4.452 & 4.398 & 0.054 \\
Own Household & 0.775 & 0.873 & $-0.098^{* * *}$ & 0.877 & 0.878 & -0.001 & 0.882 & 0.889 & -0.007 \\
Number of rooms in HH & 5.869 & 6.644 & $-0.775^{* * *}$ & 6.468 & 6.701 & $-0.233^{* *}$ & 6.492 & 6.658 & -0.166 \\
Obs. & 38,287 & 5,626 & & 6,337 & 4,933 & & 2,672 & 2,244 & \\
\hline \hline
\end{tabular}

Note: ${ }^{* * *} \mathrm{p}<0.01,{ }^{* *} \mathrm{p}<0.05,{ }^{*} \mathrm{p}<0.1$. For primary education, number of observations is smaller due to missing values.

Figure 3 - Probability of Treatment: Female Pensioners in Household

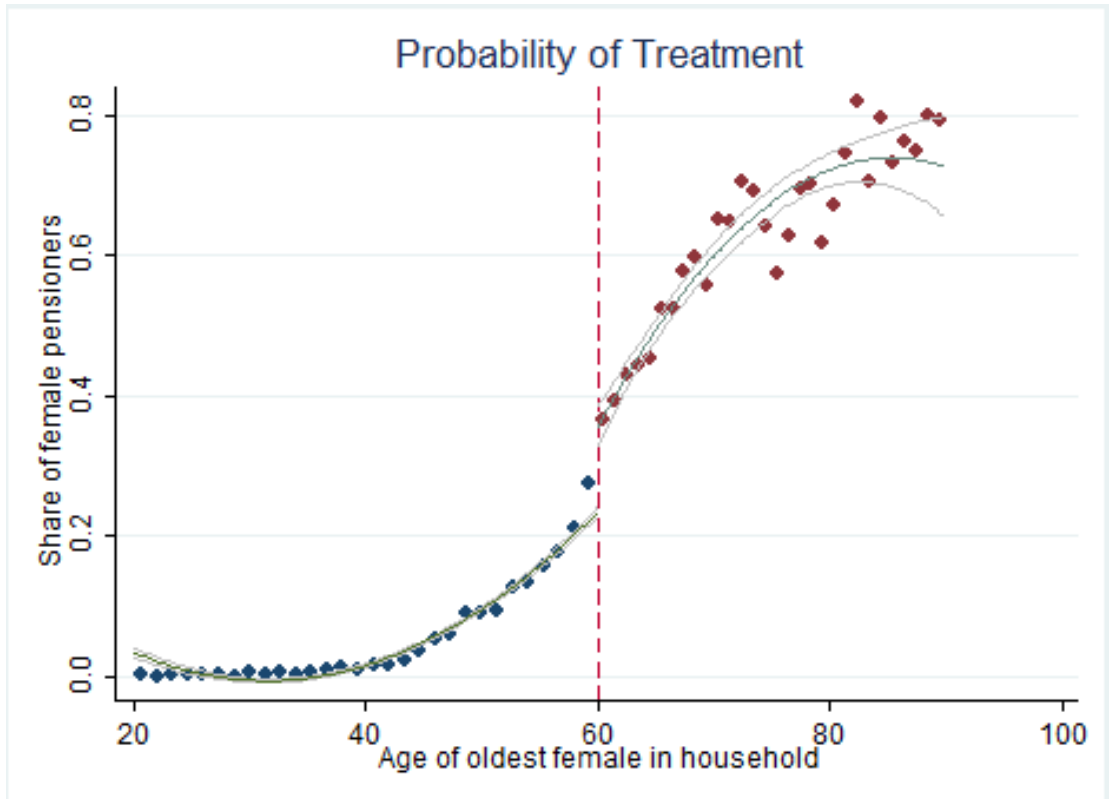

Graph of the mean of female pensioners in household conditional on the age of the oldest female in the household. 30 bins were used on each side of the cutoff and a quadratic line of best fit with a $95 \%$ confidence interval was included.

Also, it is important to show that pension eligibility is associated with pension status. In Figure 1 in Section 3, we showed that there was a discontinuity at the cutoff at age 60. Similar to the previous figure, in Figure 3 we have the conditional probability of a household having a female pensioner given the age of the oldest female in the household. As before, there is a discontinuity at the age of 60 . 
Furthermore, Table 7 presents results similar to the findings in figures 1 and 3 . The first column presents the results of the probability of a female receiving pension benefits given that she has reached 60 years old. The estimates show a positive and highly statistically significant probability. The second column presents the probability of a household having a female pensioner given that there is a female 60 years or older. This differs from the first column in that the probability is now seen at the household level, as with the case of Figure 3. Here, the probability is also positive and statistically significant. These estimates indicate an increase in the probability of being a pensioner of less than $10 \%$ for females older than 60 . Although this is a small probability, this may affect the strength of our instrument but it does not invalidate our identification strategy.

Table 7 - Probability of Treatment and Liquidity Shock in Household

\begin{tabular}{|c|c|c|c|c|}
\hline & \multirow[b]{2}{*}{$\begin{array}{c}\text { Female } \\
\text { pensioner }\end{array}$} & \multirow[b]{2}{*}{$\begin{array}{c}\text { Female } \\
\text { pensioner } \\
\text { in } \mathrm{HH} \\
\end{array}$} & \multicolumn{2}{|c|}{ Only HH with females 50-75 } \\
\hline & & & $\begin{array}{l}\text { Female } \\
\text { pensioner } \\
\text { in } \mathrm{HH}\end{array}$ & $\begin{array}{c}\text { Total per capita } \\
\text { HH income } \\
\text { (in logs })\end{array}$ \\
\hline Female older than 60 & $\begin{array}{l}0.091^{* * *} \\
(0.007)\end{array}$ & & & \\
\hline $\begin{array}{l}\text { Female older than } 60 \\
\text { in } \mathrm{HH}\end{array}$ & & $\begin{array}{c}0.090 * * * \\
(0.010)\end{array}$ & $\begin{array}{c}0.063^{* *} \\
(0.027)\end{array}$ & $\begin{array}{c}0.165^{* *} \\
(0.075)\end{array}$ \\
\hline Observations & 98,531 & 43,913 & 6,435 & 6,427 \\
\hline R-squared & 0.368 & 0.369 & 0.211 & 0.040 \\
\hline
\end{tabular}

Note: ${ }^{* * *} \mathrm{p}<0.01,{ }^{* *} \mathrm{p}<0.05,{ }^{*} \mathrm{p}<0.1$. Standard errors in parentheses. For regressions in columns one and two, only females below 90 years of age where considered. Regressions included a third degree polynomial expansion in the age of females (age of the oldest female in the household for column two regression) on either side of the cutoff of age 60 . For regressions on column three and four, a second degree polynomial on either side of the cutoff was included.

Next in column 3 we have the same result as in column 2, the probability of a household having a female pensioner, given that there is a female 60 years or older, but only for households with at least a female between the ages of 50 to 75 . In this case, the estimated probability is smaller but still positive and statistically significant. Lastly, 
to show that having a pensioner in the household results in a liquidity shock to the household, the last column in Table 7 presents the results of the impact of having a female 60 years or older on household's total income per capita. The result indicates a positive and statistically significant effect, validating our assumption that having a female pensioner in the household results in a liquidity shock to household income.

\subsection{Two-Stage Least Squares Results}

The main results of the estimation strategy are presented below. Results are of a twostage least squares estimation as specified in equation [1] for all households in the sample with at least one female between the ages of 50 and 75 . In this case, the age of the oldest female in the household is centered at the cutoff (60 years of age) and different polynomial expansions in the age of the oldest female in the household are included. As previously discussed, linear, quadratic, and cubic functional forms, with and without interactions are used in the literature. In order to not rely too much on the correct specification of the polynomial forms, results are tested using different functional specifications. All regressions include a control for households with a male pensioner and the age of the oldest male in the household. Standard errors are robust to heteroskedasticity.

Table 8 presents the results for the 2SLS specification including linear, quadratic and cubic polynomials. ${ }^{2}$ The different columns indicate different polynomial specifications and whether controls are included. Column 1 corresponds to the results using an OLS estimation where the effect of having a female pensioner in the household is not instrumented.

The first four rows include results relating to total value of investments in logarithmic form made by the entrepreneur, the probability indicating whether the entrepreneur invested in the business, the probability of whether the business owned by the entrepreneur encountered difficulties, and for the probability of the entrepreneur having used an informal source of credit. ${ }^{3}$ Column 1 results are for an OLS estimation of the effects of having a female pensioner in the household on entrepreneurial decisions. The effects appear to have

2 Further functional forms were also tested. See section A3 in the Appendix.

3 See Table A1 in the Appendix for an explanation of the outcome variables. 
Table 8 - Effcts of a Liquidity Shock on Entrepreneurial Decisions

\begin{tabular}{|c|c|c|c|c|c|c|c|c|}
\hline \multirow[t]{4}{*}{ Treatment Effect } & \multicolumn{8}{|c|}{ Female Pensioner in Household } \\
\hline & \multirow{3}{*}{$\begin{array}{c}\begin{array}{c}\text { OLS } \\
\text { Results }\end{array} \\
(1)\end{array}$} & \multicolumn{6}{|c|}{ 2SLS Results } & \multirow[b]{3}{*}{ Observations } \\
\hline & & \multicolumn{3}{|c|}{ No controls } & \multicolumn{3}{|c|}{ With Controls } & \\
\hline & & $(2)$ & $(3)$ & $(4)$ & $(5)$ & $(6)$ & $(7)$ & \\
\hline investments & $\begin{array}{c}0.043 \\
(0.096)\end{array}$ & $\begin{array}{l}-0.395 \\
(1.024)\end{array}$ & $\begin{array}{l}-0.137 \\
(1.219)\end{array}$ & $\begin{array}{c}0.611 \\
(1.486)\end{array}$ & $\begin{array}{l}-0.607 \\
(1.098)\end{array}$ & $\begin{array}{l}-0.340 \\
(1.246)\end{array}$ & $\begin{array}{c}0.621 \\
(1.516)\end{array}$ & 4,813 \\
\hline invested & $\begin{array}{c}0.007 \\
(0.014)\end{array}$ & $\begin{array}{l}-0.040 \\
(0.148)\end{array}$ & $\begin{array}{l}-0.049 \\
(0.176)\end{array}$ & $\begin{array}{c}0.045 \\
(0.214)\end{array}$ & $\begin{array}{l}-0.064 \\
(0.159)\end{array}$ & $\begin{array}{l}-0.073 \\
(0.180)\end{array}$ & $\begin{array}{c}0.050 \\
(0.219)\end{array}$ & 4,816 \\
\hline difficulties & $\begin{array}{l}-0.012 \\
(0.015)\end{array}$ & $\begin{array}{l}-0.035 \\
(0.153)\end{array}$ & $\begin{array}{l}-0.015 \\
(0.180)\end{array}$ & $\begin{array}{c}0.009 \\
(0.222)\end{array}$ & $\begin{array}{c}0.035 \\
(0.159)\end{array}$ & $\begin{array}{c}0.006 \\
(0.181)\end{array}$ & $\begin{array}{c}0.029 \\
(0.222)\end{array}$ & 6,424 \\
\hline informal credit & $\begin{array}{l}-0.004 \\
(0.009)\end{array}$ & $\begin{array}{l}-0.068 \\
(0.091)\end{array}$ & $\begin{array}{l}-0.017 \\
(0.106)\end{array}$ & $\begin{array}{l}-0.049 \\
(0.131)\end{array}$ & $\begin{array}{l}-0.058 \\
(0.095)\end{array}$ & $\begin{array}{l}-0.010 \\
(0.107)\end{array}$ & $\begin{array}{l}-0.030 \\
(0.131)\end{array}$ & 6,428 \\
\hline future plans & $\begin{array}{l}-0.003 \\
(0.014)\end{array}$ & $\begin{array}{l}-0.034 \\
(0.147)\end{array}$ & $\begin{array}{c}0.056 \\
(0.174)\end{array}$ & $\begin{array}{c}0.042 \\
(0.212)\end{array}$ & $\begin{array}{c}0.072 \\
(0.151)\end{array}$ & $\begin{array}{c}0.084 \\
(0.173)\end{array}$ & $\begin{array}{c}0.118 \\
(0.211)\end{array}$ & 6,435 \\
\hline leave business & $\begin{array}{c}-0.015^{*} \\
(0.009)\end{array}$ & $\begin{array}{c}-0.159^{*} \\
(0.093)\end{array}$ & $\begin{array}{c}-0.300^{* *} \\
(0.119)\end{array}$ & $\begin{array}{c}-0.392^{* *} \\
(0.154)\end{array}$ & $\begin{array}{c}-0.205^{* *} \\
(0.097)\end{array}$ & $\begin{array}{c}-0.319^{* * *} \\
(0.119)\end{array}$ & $\begin{array}{c}-0.401^{* * *} \\
(0.152)\end{array}$ & 6,435 \\
\hline employer & $\begin{array}{l}-0.013 \\
(0.010)\end{array}$ & $\begin{array}{c}0.163 \\
(0.108)\end{array}$ & $\begin{array}{l}0.247^{*} \\
(0.130)\end{array}$ & $\begin{array}{c}0.247 \\
(0.160)\end{array}$ & $\begin{array}{l}0.198^{*} \\
(0.114)\end{array}$ & $\begin{array}{l}0.250^{*} \\
(0.131)\end{array}$ & $\begin{array}{c}0.264 \\
(0.162)\end{array}$ & 6,435 \\
\hline $\begin{array}{l}\text { ploynomial } \\
\text { controls }\end{array}$ & $\begin{array}{c}\text { quadratic } \\
\text { YES }\end{array}$ & $\begin{array}{c}\text { linear } \\
\mathrm{NO}\end{array}$ & $\begin{array}{c}\text { quadratic } \\
\text { NO }\end{array}$ & $\begin{array}{c}\text { cubic } \\
\text { NO }\end{array}$ & $\begin{array}{l}\text { linear } \\
\text { YES }\end{array}$ & $\begin{array}{c}\text { quadratic } \\
\text { YES }\end{array}$ & $\begin{array}{l}\text { cubic } \\
\text { YES }\end{array}$ & \\
\hline
\end{tabular}

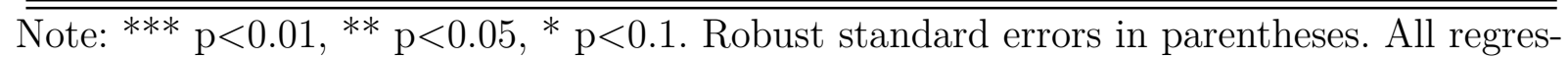
sions include a dummy controlling for households with a male pensioner and the age of the oldest male in the household. Controls include household controls, region controls, and entrepreneur demographic characteristics. For the OLS regression, controls also include age of the oldest female in the household and age of the oldest female in the household squared, not centered at the cutoff.

the expected sign if we are in the presence of liquidity constraints, but none of these effects are statistically significant.

Next, the following three rows in Table 8 present the results referring to the probability of expansion of the business in the future, the probability of the entrepreneur leaving the business in the future, and the probability of the entrepreneur being an employer and having at least 5 employees instead of being a self-employed individual. For the OLS results in column 1, both the probability of expanding the business in the future and the probability of the entrepreneur being an employer have an opposite sign than what would be expected if individuals were liquidity constrained. However, the probability of the 
individual leaving the business is negative and statistically significant. The variable "leave business"should be interpreted as a probability of leaving the business, because of struggles or difficulties, to look for other opportunities outside of entrepreneurship. Therefore, this result suggests that having a liquidity shock in the household diminishes the need for the entrepreneur to look for a salaried job and enables him to stay with the business, indicating the presence of liquidity constraints. It should be noted that the probability of leaving the business is a self-reported measure. Individuals appear to react to a liquidity shock as if it were a protection against risks, allowing them to continue in the business with a secure income.

As previously discussed, OLS results are probably biased but is difficult to identify the direction of this bias. It could be that households with pensioners have individuals with more work experience and ability. This could positively affect entrepreneurial decisions since individuals with higher ability are usually more successful allowing them to invest more, have less probability of having difficulties, etc. However, there could be a negative bias, where households with pensioners are more risk-averse and therefore invest less in their business.

When looking at the results using a 2SLS estimation, columns 2-4, the outcome effects relating to investments and difficulties are not significant for all functional form specifications. Also, for some functional specifications they appear to have the opposite sign than what we would expect if these individuals were suffering liquidity constraints. Adding controls, columns 5-7, does not change the significance of these effects. Furthermore, it appears that there is a negative effect on the probability of using informal credit sources for households with a female pensioner. However, this effect is not statistically significant for both estimates with and without controls. ${ }^{4}$

4 The results relating to value of investments, probability of investments and probability of having difficulties have a reference period of one year. The results relating to use of informal credit have a reference period of three months (see table A1 in the Appendix for a detailed definition of the outcome variables). For households with females just around the cutoff, it is difficult to determine whether they were indeed treated (had a pensioner or not) at the time of the reference period. Given this issue, we also tested these results not including households where the oldest female was 60 and changing the discontinuity to 61 . No significant results were found. These results are reported in Table A4 in the Appendix. 
Estimates regarding the effect of a liquidity shock on the probability of an increase of the business in the future are not consistent across the different functional forms and are not statistically significant. Including controls does not change the results. For the effect of having a female pensioner in the household on the probability of the entrepreneur leaving the business, the probability is negative and statistically significant. This shows that a liquidity shock to the household decreases the probability of the entrepreneur leaving the business by around 10 to 40 percentage points. Results are robust when adding controls and are similar in magnitude. The coefficient of the 2SLS is significantly larger in magnitude compared to the OLS estimate, maybe indicating the OLS had a downward bias. This large coefficient could also be indicative of a problem with our instrument however first-stage statistics indicated a strong instrument. ${ }^{5}$ Furthermore, the effect of having a female pensioner in the household on the probability of being an employer is positive and statistically significant but only for some of the functional specifications. Here, having a liquidity shock in the household increases the probability of the entrepreneur being an employer by approximately 25 percentage points. When adding controls, results are significant when using a linear and quadratic polynomial. ${ }^{6}$

\subsection{Discussion of Results}

Results indicate that a liquidity shock in the household via the receipt of pension benefits by female elders has no statistically significant effects on investment decisions and on measures of business performance, future plans, and on the use of informal credit sources. There is a significant positive effect on the probability of the entrepreneur being an employer instead of a self-employed individual. Moreover, there is a significant effect related to the transition into self-employment, in this case remaining a self-employed individual instead of leaving the business and becoming a wage-worker.

An explanation for the lack of effects found on investment decisions could be

$5 \quad$ See Table A2 in the Appendix for First-Stage Statistics.

6 To check for further robustness of results, we also checked these results by considering only data in smaller neighborhoods around the discontinuity. See section A5 in the Appendix. 
that the sample used in this study is restricted to small business owners. The literature concerned with identifying credit constraints by looking at the impacts of liquidity shocks on entrepreneurship usually focuses on the effects of shocks on capital. In this case, businesses are small and mostly labor-intensive, therefore not seeing an effect of a liquidity shock on investments does not mean they are not suffering credit constraints. This is more evident when considering the significant results found on the probability of being an employer. Liquidity shocks appear to not have an effect on investment decisions but have an effect on the scale of the business in relation to hiring workers, indicating these individuals could be suffering liquidity constraints.

Furthermore, the effect found of a decrease on the probability of leaving the business is also an indication that these individuals are suffering constraints. Since this is a selfreported measure, this result can be interpreted as a protection against shocks. Considering that entrepreneurial activities are risky and individuals are risk-averse, individuals perceive this liquidity shock as a protection. Having a guaranteed income, protects individuals against unexpected shocks and allows them to continue in the business.

The results found contradict an explanation related to the idea that small business owners in the informal sector engage in entrepreneurial activities as a survival mechanism, and when the household starts receiving pension income, there is no longer a need to continue in the business. This is in line with the findings of Das et al. (2003). They found that in urban areas in India self-employment in household enterprises was more in the nature of a survival strategy for individuals with low levels of education.

Lastly, the lack of results might also be related to the fact that the sample is rather heterogeneous. However, attempts at stratifying the sample by region (dividing it into two groups: the poorest regions and the richest regions in the country) and by gender of the head of household did not result in significant effects and also resulted in a significantly reduced subsample. 



\section{Conclusion}

The objective of this study was to analyze how liquidity shocks affected households' decisions related to entrepreneurial activities in order to identify whether households were liquidity constrained. Based on the consumption smoothing/permanent income hypothesis, this study focused on households' responses to anticipated income shocks since, under complete markets, decisions should not be affected by a liquidity shock when the timing and amount of that shock are known.

We used pension benefits as an anticipated income shock and compared decisions related to entrepreneurial activities of Brazilian households with a female nearly eligible to receive pension benefits to households with a female receiving benefits. We exploited the fact that eligibility rules for old age pension were partially determined by age and used a Fuzzy Regression Discontinuity Design to estimate a causal effect.

The results obtained showed that the probability of an entrepreneur leaving the business for a salaried job decreased for individuals in households that received this liquidity shock. There was also an increase on the probability of the entrepreneur being an employer instead of a self-employed individual for households with a female pensioner. There were no significant effects on investment decisions, business performance, and use of informal credit for households having received a liquidity shock.

The lack of effects on investment decisions and business performance are not necessarily evidence that these individuals are not credit constrained, especially when we think about the nature of the data used. Our sample was restricted to small business owners engaged in mostly labor-intensive, low-capital activities. Therefore, the channel through which these individuals might be affected by credit constraints differ from what is usually studied in the literature. The significant effects found on the probability of being an employer reflect this point. Moreover, the effect found on the probability of leaving the business are further evidence that these individuals are constrained. Receiving a liquidity shock in this case acts as a buffer, insuring an income, protecting entrepreneurs against risks, and allowing them to continue with the entrepreneurial activity. 
The results obtained allowed us to know more about the behavior of small entrepreneurs. We could see that although investment decisions were not affected, individuals reacted as if they were constrained in other decisions. Results therefore lead us to the conclusion that Brazilian small business owners in the informal sector of the economy are liquidity constrained. 


\section{Referências}

AGHION, P.; BOLTON, P. A theory of trickle-down growth and development. The Review of Economic Studies, v. 64, n. 2, p. 151-172, 1997.

ANGRIST, J. D.; PISCHKE, J.-S. Mostly harmless econometrics: An empiricist's companion. [S.l.]: Princeton university press, 2008.

ASSUNÇÃO, J. J.; ALVES, L. S. Restrições de crédito e decisões intra-familiares. Revista Brasileira de Economia, SciELO, v. 61, n. 2, p. 201-229, 2007.

BANERJEE, A. V.; DUFLO, E. Growth theory through the lens of development economics. Handbook of economic growth, Elsevier, v. 1, n. 1, p. 473-552, 2005.

BANERJEE, A. V.; NEWMAN, A. F. Occupational choice and the process of development. Journal of political economy, v. 101, n. 2, p. 274-298, 1993.

BARDHAN, P.; UDRY, C. Development microeconomics. [S.l.]: Oxford University Press, 1999.

BARROS, R. Paes de et al. Markets, the State and the Dynamics of Inequality: Brazil's Case Study. New York, 2008.

BONTURI, M. The Brazilian Pension System: Recent Reforms and Challenges Ahead. [S.l.], 2002. Disponível em: <http://EconPapers.repec.org/RePEc:oec:ecoaaa:340-en>.

CAGETTI, M.; NARDI, M. D. Entrepreneurship, frictions, and wealth. Journal of political Economy, v. 114, n. 5, p. 835-870, 2006.

CARVALHO, I. D. Old-age benefits and retirement decisions of rural elderly in brazil. Journal of Development Economics, Elsevier, v. 86, n. 1, p. 129-146, 2008.

CARVALHO, I. D. Household income as a determinant of child labor and school enrollment in brazil: Evidence from a social security reform. Economic Development and Cultural Change, JSTOR, v. 60, n. 2, p. 399-435, 2012.

DAS, M. et al. The other side of self-employment: household enterprises in India. [S.l.]: World Bank, 2003.

DUNN, T.; HOLTZ-EAKIN, D. Financial capital, human capital, and the transition to self-employment: Evidence from intergenerational links. Journal of Labor Economics, v. 18 , n. 2, p. 282-305, 2000.

EDMONDS, E. V. Child labor and schooling responses to anticipated income in south africa. Journal of Development Economics, Elsevier, v. 81, n. 2, p. 386-414, 2006.

EVANS, D. S.; JOVANOVIC, B. An estimated model of entrepreneurial choice under liquidity constraints. The Journal of Political Economy, The University of Chicago Press, v. 97, n. 4, p. 808-827, 1989.

GALOR, O.; ZEIRA, J. Income distribution and macroeconomics. The review of economic studies, v. 60, n. 1, p. 35-52, 1993. 
GHATAK, M.; JIANG, N. N.-H. A simple model of inequality, occupational choice, and development. Journal of development Economics, v. 69, n. 1, p. 205-226, 2002.

HAHN, J.; TODD, P.; KLAAUW, W. Van der. Identification and estimation of treatment effects with a regression-discontinuity design. Econometrica, v. 69, n. 1, p. 201-209, 2001.

HOLTZ-EAKIN, D.; JOULFAIAN, D.; ROSEN, H. S. Entrepreneurial decisions and liquidity constraints. The RAND Journal of Economics, Wiley on behalf of RAND Corporation, v. 25, n. 2, p. 334-347, 1994. Disponível em: < http: //www.jstor.org/stable/2555834>.

IMBENS, G. W.; LEMIEUX, T. Regression discontinuity designs: A guide to practice. Journal of econometrics, Elsevier, v. 142, n. 2, p. 615-635, 2008.

Instituto Brasileiro de Geografia e Estatística. Economia Informal Urbana. Rio de Janeiro: IBGE, 2003.

International Labour Office. Measuring informality a statistical manual on the informal sector and informal employment. Geneva: ILO, 2013. Disponível em: <http://www.ilo.org/public/libdoc/ilo/2013/480862.pdf>.

JACOB, R. T. et al. A practical guide to regression discontinuity. [S.l.]: MDRC, 2012.

JAPPELLI, T.; PISTAFERRI, L. The consumption response to income changes. Annual Review of Economics, v. 2, n. 1, p. 479-506, 2010.

LEE, D. S.; LEMIEUX, T. Regression discontinuity designs in economics. Journal of Economic Literature, v. 48, n. 2, p. 281-355, 2010. Disponível em: $<$ http://www.aeaweb.org/articles.php?doi=10.1257/jel.48.2.281>.

LINDH, T.; OHLSSON, H. Self-employment and windfall gains: Evidence from the swedish lottery. The Economic Journal, JSTOR, v. 106, p. 1515-1526, 1996.

MCCRARY, J. Manipulation of the running variable in the regression discontinuity design: A density test. Journal of Econometrics, Elsevier, v. 142, n. 2, p. 698-714, 2008.

REIS, M. C.; CAMARGO, J. M. Impactos de aposentadorias e pensões sobre a educação e a participação dos jovens na força de trabalho. Pesquisa e Planejamento Econômico, Rio de Janeiro, v. 37, n. 2, p. 221-246, 2007. 


\section{Appendix}

\section{A1. Explanation of Outcome Variables}

Table A1: Outcome Variable Definitions

Variable definition (survey questions)

investments Total value of investments made in reference period

invested $\quad=1$ if entrepreneur invested in reference period

difficulties $\quad=1$ if business encountered difficulties in reference period

These difficulties include: reduction in employees, reduction

in productive capacity (installations and equipments),

reduction in business activities, reduction in hours of operation

informal credit $=1$ if entrepreneur obtained credit from an informal source of credit

Sources include: friends and relatives, other businesses, other suppliers, money lenders, inheritance

future plans $\quad=1$ if entrepreneur has plans to expand the business in the future

leave business $\quad=1$ if entrepreneur plans to leave the business

employer $\quad=1$ if entrepreneur is an employer with up to five employees instead of a self-employed individual

Note: Reference period refers to start of previous year of the survey until the end of the previous month of the day of the interview. 


\section{A2. First-Stage Regression Results}

Table A2: First-Stage Results

\begin{tabular}{|c|c|c|c|}
\hline \multirow{2}{*}{$\begin{array}{l}\text { Variable } \\
\text { Polynomial }\end{array}$} & \multicolumn{3}{|c|}{ hh has a female pensioner } \\
\hline & $\begin{array}{c}\text { linear } \\
(1)\end{array}$ & $\begin{array}{c}\text { quadratic } \\
(2)\end{array}$ & $\begin{array}{c}\text { cubic } \\
(3)\end{array}$ \\
\hline $\begin{array}{l}\text { Second Stage DV: investments } \\
\text { hh has a female older than } 60\end{array}$ & $\begin{array}{c}0.134^{* * *} \\
(0.023)\end{array}$ & $\begin{array}{l}0.126^{* * *} \\
(0.024)\end{array}$ & $\begin{array}{c}0.107^{* * *} \\
(0.026)\end{array}$ \\
\hline First-Stage F-statistic & 35.245 & 26.831 & 16.852 \\
\hline $\mathrm{P}$-value & 0.000 & 0.000 & 0.000 \\
\hline $\begin{array}{l}\text { Second Stage DV: invested } \\
\text { hh has a female older than } 60\end{array}$ & $\begin{array}{c}0.134^{* * * *} \\
(0.023)\end{array}$ & $\begin{array}{c}0.126^{* * *} \\
(0.024)\end{array}$ & $\begin{array}{c}0.107^{* * *} \\
(0.026)\end{array}$ \\
\hline First-Stage F-statistic & 35.150 & 26.788 & 16.808 \\
\hline P-value & 0.000 & 0.000 & 0.000 \\
\hline $\begin{array}{l}\text { Second Stage DV: difficulties } \\
\text { hh has a female older than } 60\end{array}$ & $\begin{array}{c}0.136^{* * *} \\
(0.020)\end{array}$ & $\begin{array}{c}0.132^{* * *} \\
(0.021)\end{array}$ & $\begin{array}{l}0.111^{* * *} \\
(0.023)\end{array}$ \\
\hline First-Stage F-statistic & 48.949 & 38.635 & 23.878 \\
\hline $\mathrm{P}$-value & 0.000 & 0.000 & 0.000 \\
\hline $\begin{array}{l}\text { Second Stage DV: informal credit } \\
\text { hh has a female older than } 60\end{array}$ & $\begin{array}{c}0.137^{* * *} * \\
(0.020)\end{array}$ & $\begin{array}{c}0.133^{* * *} \\
(0.021)\end{array}$ & $\begin{array}{c}0.112^{* * * *} \\
(0.023)\end{array}$ \\
\hline First-Stage F-statistic & 49.787 & 39.439 & 24.510 \\
\hline $\mathrm{P}$-value & 0.000 & 0.000 & 0.000 \\
\hline $\begin{array}{l}\text { Second Stage DV: future plans } \\
\text { hh has a female older than } 60\end{array}$ & $\begin{array}{c}0.137^{* * *} \\
(0.019)\end{array}$ & $\begin{array}{c}0.133^{* * *} \\
(0.021)\end{array}$ & $\begin{array}{c}0.112^{* * *} \\
(0.023)\end{array}$ \\
\hline First-Stage F-statistic & 49.952 & 39.330 & 24.551 \\
\hline P-value & 0.000 & 0.000 & 0.000 \\
\hline $\begin{array}{l}\text { Second Stage DV: leave business } \\
\text { hh has a female older than } 60\end{array}$ & $\begin{array}{c}0.137^{* * *} \\
(0.019)\end{array}$ & $\begin{array}{c}0.133^{* * *} \\
(0.021)\end{array}$ & $\begin{array}{c}0.112^{* * *} \\
(0.023)\end{array}$ \\
\hline First-Stage F-statistic & 49.952 & 39.330 & 24.551 \\
\hline $\mathrm{P}$-value & 0.000 & 0.000 & 0.000 \\
\hline $\begin{array}{l}\text { Second Stage DV: employer } \\
\text { hh has a female older than } 60\end{array}$ & $\begin{array}{c}0.137^{* * * *} \\
(0.019)\end{array}$ & $\begin{array}{c}0.133^{* * *} \\
(0.021)\end{array}$ & $\begin{array}{c}0.112^{* * *} \\
(0.023)\end{array}$ \\
\hline First-Stage F-statistic & 49.952 & 39.330 & 24.551 \\
\hline P-value & 0.000 & 0.000 & 0.000 \\
\hline
\end{tabular}

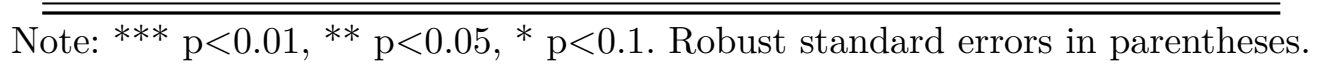

As noted in Stock, Wright, and Yogo (2002), a good rule of thumb to determine the strength of an instrument is to check whether the F-statistic is above 10 (ANGRIST; PISCHKE, 2008). 


\section{A3. Further Functional Forms}

Table A3 presents the results for the 2SLS specification including among controls interaction terms between the polynomial terms of age of the oldest female in the household and the effective treatment and also use as instrumental variable the interactions between the assignment to treatment dummy and the age polynomial, as noted in Angrist and Pischke(2008). This allows separate functions on either side of the cutoff. A quadratic polynomial with an interaction resulted in a low a first-stage f-statistic for some of the outcome variables. Also, the first-stage coefficient of the assignment to treatment, $\gamma_{0}$ in equation [2] remained positive but only statistically significant at the 5 and 10 percent levels. This could be an indication of a weak instrument and therefore results were not included. A cubic polynomial with an interaction was not tested because the first-stage coefficient of the assignment to treatment variable, $\gamma_{0}$, was not significant.

The different columns indicate whether controls are included. ${ }^{1}$ Here, results relating to investment decisions, difficulties encountered, use of informal credit, and plans to expand the business in the future continue to be statistically insignificant. It appears that for these entrepreneurial decisions, a liquidity shock has no effect. Looking at the effects of a shock on the probability of leaving the business, the effect is significant. This effect is robust when including controls and similar in magnitude, indicating a decrease in the probability of around 20 to 25 percentage points. Lastly, the effects of a liquidity shock on the probability of being an employer instead of self-employed are positive and statistically significant, indicating an effect of an increase of around 20 percentage points.

$\overline{1}$ First-stage results were not included. Both instruments were highly correlated with the endogenous variables for all regressions and F-statistics indicated strong instruments. Results are available upon request. 
Table A3: Further Functional Forms

\begin{tabular}{|c|c|c|c|}
\hline \multirow[t]{3}{*}{ Treatment Effect } & \multicolumn{2}{|c|}{ Female Pensioner in Household } & \multirow[b]{3}{*}{ Observations } \\
\hline & No controls & With controls & \\
\hline & $(1)$ & $(2)$ & \\
\hline investments & $\begin{array}{l}-0.680 \\
(1.096)\end{array}$ & $\begin{array}{c}-1.012 \\
(1.136)\end{array}$ & 4,813 \\
\hline invested & $\begin{array}{l}-0.103 \\
(0.157)\end{array}$ & $\begin{array}{l}-0.144 \\
(0.163)\end{array}$ & 4,816 \\
\hline difficulties & $\begin{array}{l}-0.018 \\
(0.160)\end{array}$ & $\begin{array}{c}0.007 \\
(0.162)\end{array}$ & 6,424 \\
\hline informal credit & $\begin{array}{l}-0.004 \\
(0.095)\end{array}$ & $\begin{array}{c}0.005 \\
(0.097)\end{array}$ & 6,428 \\
\hline future plans & $\begin{array}{c}0.038 \\
(0.155)\end{array}$ & $\begin{array}{c}0.046 \\
(0.155)\end{array}$ & 6,435 \\
\hline leave business & $\begin{array}{c}-0.227^{* *} \\
(0.103)\end{array}$ & $\begin{array}{c}-0.251^{* *} \\
(0.103)\end{array}$ & 6,435 \\
\hline employer & $\begin{array}{l}0.226^{*} \\
(0.114)\end{array}$ & $\begin{array}{l}0.223^{*} \\
(0.116)\end{array}$ & 6,435 \\
\hline ploynomial & $\begin{array}{c}\text { linear } \\
\text { interaction }\end{array}$ & $\begin{array}{c}\text { linear } \\
\text { interaction }\end{array}$ & \\
\hline controls & NO & YES & \\
\hline
\end{tabular}

$\overline{\text { Note: }{ }^{* * *} \mathrm{p}<0.01,{ }^{*} * \mathrm{p}<0.05,{ }^{*} \mathrm{p}<0.1 \text {. Robust standard errors in }}$ parentheses. All regressions include a dummy controlling for households with a male pensioner and the age of the oldest male in the household. Controls include household controls, region controls, and entrepreneur demographic characteristics. 


\section{A4. Results Not Including Observations at the Cutoff}

Table A4: 2SLS Results Not Including Observations at the Cutoff

\begin{tabular}{|c|c|c|c|c|c|c|c|}
\hline \multirow[t]{3}{*}{ Treatment Effect } & \multicolumn{6}{|c|}{ Female Pensioner in Household } & \multirow[b]{3}{*}{ Observations } \\
\hline & \multicolumn{3}{|c|}{ No Controls } & \multicolumn{3}{|c|}{ With controls } & \\
\hline & $(1)$ & $(2)$ & $(3)$ & $(4)$ & $(5)$ & $(6)$ & \\
\hline investments & $\begin{array}{l}-0.694 \\
(0.991)\end{array}$ & $\begin{array}{c}-0.496 \\
(1.143)\end{array}$ & $\begin{array}{c}0.381 \\
(1.468)\end{array}$ & $\begin{array}{l}-0.948 \\
(1.054)\end{array}$ & $\begin{array}{l}-0.731 \\
(1.167)\end{array}$ & $\begin{array}{c}0.430 \\
(1.490)\end{array}$ & 4,586 \\
\hline invested & $\begin{array}{l}-0.101 \\
(0.143)\end{array}$ & $\begin{array}{l}-0.115 \\
(0.164)\end{array}$ & $\begin{array}{l}-0.019 \\
(0.211)\end{array}$ & $\begin{array}{l}-0.131 \\
(0.151)\end{array}$ & $\begin{array}{l}-0.141 \\
(0.168)\end{array}$ & $\begin{array}{l}-0.004 \\
(0.214)\end{array}$ & 4,589 \\
\hline difficulties & $\begin{array}{l}0.0315 \\
(0.149)\end{array}$ & $\begin{array}{c}0.055 \\
(0.171)\end{array}$ & $\begin{array}{c}0.133 \\
(0.229)\end{array}$ & $\begin{array}{c}0.094 \\
(0.155)\end{array}$ & $\begin{array}{c}0.072 \\
(0.172)\end{array}$ & $\begin{array}{c}0.149 \\
(0.229)\end{array}$ & 6,124 \\
\hline informal credit & $\begin{array}{l}-0.055 \\
(0.088)\end{array}$ & $\begin{array}{l}-0.080 \\
(0.100)\end{array}$ & $\begin{array}{l}-0.051 \\
(0.133)\end{array}$ & $\begin{array}{l}-0.057 \\
(0.092)\end{array}$ & $\begin{array}{l}-0.012 \\
(0.102)\end{array}$ & $\begin{array}{l}-0.045 \\
(0.133)\end{array}$ & 6,128 \\
\hline $\begin{array}{l}\text { ploynomial } \\
\text { controls }\end{array}$ & $\begin{array}{c}\text { linear } \\
\text { NO }\end{array}$ & $\begin{array}{c}\text { quadratic } \\
\text { NO }\end{array}$ & $\begin{array}{c}\text { cubic } \\
\text { NO }\end{array}$ & $\begin{array}{c}\text { linear } \\
\text { YES }\end{array}$ & $\begin{array}{c}\text { quadratic } \\
\text { YES }\end{array}$ & $\begin{array}{c}\text { cubic } \\
\text { YES }\end{array}$ & \\
\hline
\end{tabular}

$\overline{\text { Note: }}{ }^{* * *} \mathrm{p}<0.01,{ }^{* *} \mathrm{p}<0.05,{ }^{*} \mathrm{p}<0.1$. Robust standard errors in parentheses. All regressions include a dummy controlling for households with a male pensioner and the age of the oldest male in the household. Controls include household controls, region controls, and entrepreneur demographic characteristics. 


\section{A5. Results Using Smaller Age Intervals}

Here, the results obtained are checked by considering only data in smaller neighborhoods around the discontinuity, a local linear regression approach. Comparing outcomes in a small neighborhood around the cutoff value allows estimation of the effects without relying extensively on the correct specification of the conditional forms. In turn, reducing the age interval also leads to a significant loss of observations. Table A5 presents the results for the effects on the probability of the entrepreneur leaving the business and on the effects on the probability of being an employer.

Table A5: 2SLS Results Using Smaller Age Intervals

\begin{tabular}{lcc}
\hline \hline Treatment Effect & \multicolumn{2}{c}{ Female pensioner in $\mathrm{HH}$} \\
Polynomial & 1st order & 2nd order \\
\hline HH with females 55-64 & & \\
\hline Leave Business & $-0.284^{* *}$ & -0.474 \\
& $(0.140)$ & $(0.399)$ \\
Employer & 0.206 & 0.197 \\
& $(0.158)$ & $(0.394)$
\end{tabular}

\begin{tabular}{lc} 
Observations & 2,841 \\
\hline HH with females 56-63 & \\
\hline Leave Business & $-0.279^{*}$ \\
& $(0.142)$ \\
Employer & 0.229 \\
& $(0.164)$
\end{tabular}

\begin{tabular}{lc} 
Observations & 2,295 \\
\hline HH with females 57-62 & \\
\hline Leave Business & -0.267 \\
& $(0.181)$ \\
Employer & 0.259 \\
& $(0.206)$
\end{tabular}

\begin{tabular}{l} 
Observations 1,785 \\
\hline \hline Note: ${ }^{* * *} \mathrm{p}<0.01,{ }^{* *} \mathrm{p}<0.05,{ }^{*} \mathrm{p}<0.1$. Robust stan- \\
dard errors in parentheses. All regressions include a \\
dummy controlling for households with a male pensi- \\
oner and the age of the oldest male in the household.
\end{tabular}

As we can see, when considering only households with at least one female between the ages of 55 to 64 , the probability of the entrepreneur leaving the business remains negative 
and statistically significant. This result doesn't hold for all polynomial specifications. With an age interval of 56 to 63 years, the result is also negative and significant. This result is no longer significant when considering only households with at least a female between the ages of 57 to 62 . However, the smaller intervals result in a significant decrease in the number of observations, and here the sign and the magnitude of the effect is similar to what was previously found. Regarding the effect of the entrepreneur being an employer instead of a self-employed individual, the effect is lost when considering smaller intervals around the cutoff. The sensitivity of this result to the smaller intervals around the cutoff question the robustness of this effect. 


\section{A6. Probability of Treatment - Males}

Figure A1: Probability of Treatment: Male Pensioners

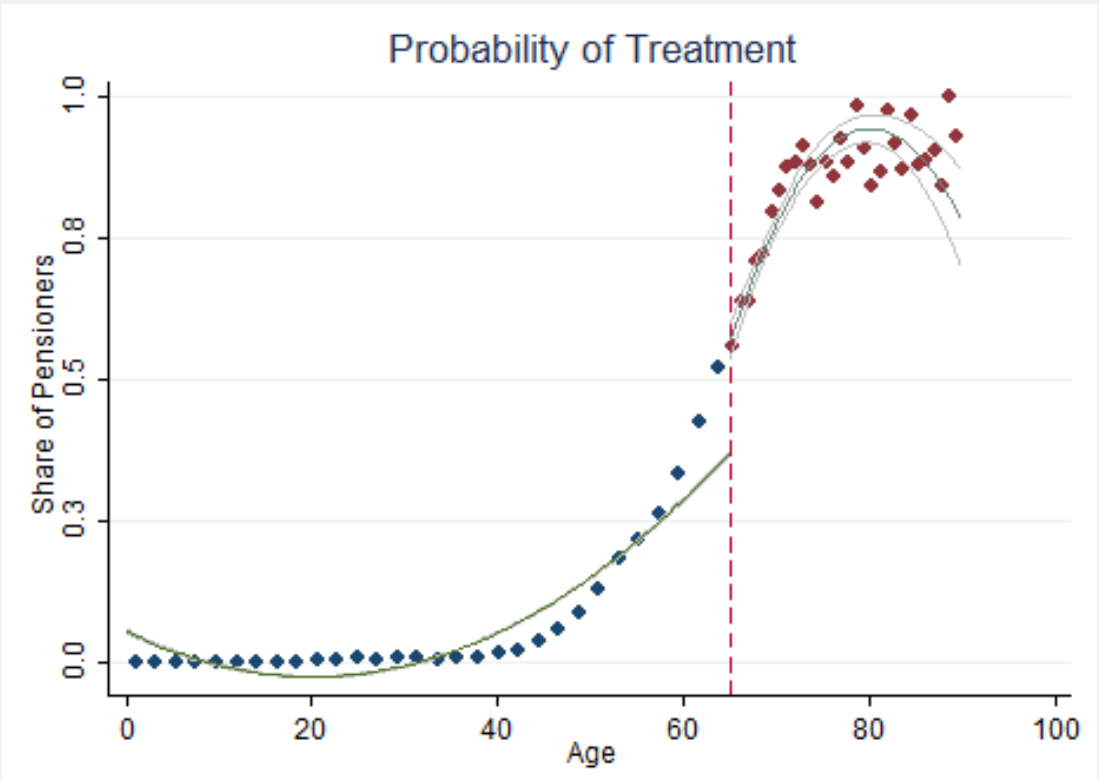

Graph of the mean of male pensioners conditional on age. 30 bins were used on each side of the cutoff and a quadratic line of best fit with a $95 \%$ confidence interval was included. 